10.2478/cer-2018-0008

\author{
GOHAR VARDANYAN*, KRZYSZTOF LEWANDOWSKI**
}

\title{
The Standard of Living of a Population: a Comparative Analysis of Armenia and Poland
}

\begin{abstract}
A population's standard of living has a special and important place in the concept of human development. Ultimately, the higher the standard of living of a population, the greater the chance for real human development, other things being equal. The standard of living in its most general sense is nothing more than a certain level of satisfaction of the population's needs because no society and no country is able to fully meet the needs of all people. The standard of living of a population cannot be expressed by any one indicator taking in both quantitative and qualitative aspects. The standard of living of a population is characterized and reflected by a system of indicators in which there is a special significance for such indicators, such as the needs of households, real incomes, private consumption, and socio-psychological satisfaction. However, in order to quantify exactly the level of standard of living, the degree of satisfaction of the needs, wealth, poverty and income stratification, as well as their causes, should be evaluated. They should be considered not only and not so much at the macroeconomic level (GDP, GNP, National Income, Consumption general fund, etc.) but also at the microeconomic level, by selecting a socioeconomic cell as an observation object, study its composition, the number of working persons in employment, and the ratio of workers, among others (Gevorgyan, Margaryan 1994, p. 52).

The aim of this paper is to compare the standard of living in Poland and Armenia. Both countries belonged to the Eastern bloc with centrally planned economies, which had an enormous impact on the whole economic and social life in both countries.
\end{abstract}

* Professor, Armenian National Agrarian University, Department of Agrobusiness and Marketing, Chair of Statistics and Biometry, Yerevan, Armenia, e-mail: vardgohar@yandex.ru

${ }^{* *}$ Ph.D., Associate Professor, University of Lodz, Faculty of Economics and Sociology, Department of World Economics and European Integration, Lodz, Poland, e-mail: krzys@uni.lodz.pl 
Keywords: standard of living, quality of life, human development

JEL: I31, P46, P52

\section{Introduction}

It is well known that in every society the main mission of the state is to apply complex measures which are aimed at improving the standard of living of the populous and which will ensure a sufficient level of welfare for it. It is obvious that there is no perfect indicator which characterizes the standard of living of a population and any applicable indicator has advantages and disadvantages. Improving the system of indicators which characterize the standard of living of the population, improving its structure and components, and ensuring a decent level of well-being have recently taken on great importance and they should become a state's dominant trajectory. This is important in terms of designing and implementing a social policy based on a comprehensive and exhaustive analysis of the indicators of quality of life (Manaseryan 2000, pp. 39-48).

Economists generally use two types of yardsticks to measure living standards. Macroeconomists use aggregate gross domestic products per capita to measure economic well-being. In contrast, microeconomists compare the distribution of disposable income across households to assess the distribution of economic well-being, expressed in terms of income per equivalent adult (or citizen). Here, comparisons of well-being are almost always relative "within nations' comparisons of many points in the income and consumption distribution" (Smeeding, Rainwater 2002, p. 2)

In order to improve the current well-being of the population, living standards which meet modern requirements should be set as a basis for the socio-economic policy. The essence of a government's social policy is to maintain a fair balance between social groups and strata of society, which will ensure better level of living conditions for all members of society. A state's social policy is directly linked to the economic situation in the country. The important issue of ensuring the economic well-being of the population in a less developed country can be achieved mainly through a radical restructuring of the economy. This would allow for economic growth and would create a stable basis for increasing the standard of living of the population (Vardanyan, Vardanyan 2008, pp. 55-58).

This paper presents the dynamics and the present state of selected economic and social indicators in Armenia and Poland. These indicators determine the standard of living in both countries to a substantial degree. 


\section{The concepts of standard of living, well-being and quality of life of a population}

The standard of living represents the satisfaction of the material and spiritual needs of mankind and enables the socio-economic situation in the given country to be understood. Mostly, the standard of living of the population is determined by the level of development of their basic needs rather than their degree of satisfaction (Manaseryan 2000, pp. 39-48).

The well-being of the population is the level of satisfaction of tangible and intangible (including spiritual goods) needs of a person or household, in both absolute and relative terms, compared to those standards or norms which are accepted in a given society or social group. The concept of well-being combines quality of life and lifestyle, reflecting the generalized complex of material and spiritual needs. The well-being of the population is conditioned by the level of acquisition of consumer goods and required services to maintain the population's healthy life in a given country, as well as by the opportunity to work within the society or to do some other activity. Increasing the welfare or well-being of the population assumes that the standard of living will also rise.

The following four levels of well-being (standard of living) are distinguished in the professional economics literature:

1. Prosperity - a satisfactory level of using benefits which ensure comprehensive human development.

2. Normal level - the natural level of rational consumption based on scientifically accepted norms, which ensure the restoration of physical and mental powers of people.

3. Poverty - in this case, the consumption of goods is at a level which is just enough to ensure the supply of labor.

4. Destitution - in this case, only the minimum of the goods and services basket which meet biological criteria is available, the consumption of which is perhaps the only opportunity for a person to maintain his life (UN Office in Armenia 2005, p. 43).

There are two major challenges in developing an appropriate approach to the evaluation of the standard of living. First, it must meet the motivation that makes us interested in the concept of the living standard. Second, the approach must nevertheless be practical in the sense of being usable for the actual assessment of the living standard. This imposes restrictions on the kinds of information that can be required and evaluation techniques that may be used (Sen 1985, p. 27)

In general, the important components of the structure of the standard of living of a population are monetary income, social security, the consumption of material goods and services, living conditions and free time. Living conditions can be divided into work, everyday living and leisure conditions. The study of the liv- 
ing conditions of the population of the Republic of Armenia is carried out with the assistance of the World Bank methodology and includes the main groups of indicators of well-being.

Quality of life describes the ability of people to act in their economic, political and cultural life, respond quickly to changes in technical, environmental and social conditions, maintain the stability of life and ensure the reproduction of viable generations, adapting to a constantly changing workforce. The concept of quality of life can be described only by a system of indicators which reflect important social characteristics from different sides. The main indicators are:

1. Working conditions and level of material well-being,

2. Education and level of professional preparedness,

3. Health.

The peculiarity of these indicators consists in the fact that they depend on social as well as physical factors (Vardanyan 2002, pp. 187-192).

Quality of life is characterized by such economic indicators as the income of the population, poverty, wealth level and property stratification. All of this means that there are differences between the well-being of the population in different countries. In the process of studying the living standards of a population, it is important to take into account so-called social norms as science-based guidelines of social processes. Typically, the following social norms are distinguished: the development of a material base of the social sphere, the income and expenditures of the population, social security and service, public consumption of material goods and paid services, living conditions, environmental conditions and protection, consumer budget, etc. Thus, social standards include the consumer budget (the basket), minimum wages, unemployment and temporary disability allowances, minimum labor and social pensions, minimum scholarship, and one-time or regular allowances to vulnerable groups of the population. In general, they form a system of minimum social guarantees which a state should provide for its citizens. Certain aspects of quality of life are described by such private indicators as socio-demographic indicators (life expectancy, fertility, mortality, and disease dynamics), indicators of economic active population (unemployment, population migration and its causes), indicators of social tensions (dynamics of political events), indicators of social development, and environmental status.

The indicators of living standards are completed by the indicators of the lifestyle of the population, which reflects the life of the population in all its sectors, such as labor, consumer, government, religious, customs and traditions, geographic and socio-political. In general, there have been two trends in the world in the last half-century. The first is that, generally, the lifestyle of the total population is improving and on the basis of that, the standard of living is rising too. At the same time, this overall progress of potential human development is combined with the rapid widening of the gap between rich and poor populations, both between rich and poor countries and within each country. Raising the quality of life and standard 
of living are the primary purposes of social development and one of the most important directions of a state's income and wage policy. The most important means of achieving this goal are the improvement in GDP growth and the mechanisms for its distribution at macro and micro levels.

\section{The comparison of standard of living of Armenia and Poland}

Both Poland and Armenia belonged to the Eastern bloc, with a centrally planned economy. This had an enormous impact on the whole economic and social life in both countries. At the beginning of the transformation process, Poland and Armenia had much lower standards of living than Western democracies.

The beginning of the transformation process was difficult in Poland. The "shock therapy" introduced by the first non-communist government brought a sharp decline in real incomes, the collapse of many inefficient enterprises and high unemployment (Kołodko, Nuti 1997, p. 12).

Nevertheless, the "Balcerowicz plan" was indispensable in putting Poland on a long-term growth path. It enabled macroeconomic stabilization, the inflow of foreign direct investments, the blossoming of the private sector, and foreign trade. The result is that the standard of living of Polish citizens has constantly grown, although not at the same pace for everyone. A distinct improvement took place in the field of environmental protection, access to education (in particular to higher education) and consumer choice.

Joining the EU was the next important stimulus to raise the standard of living in Poland. In order to gain the advantages from involvement in the Common Market, the economy of Poland had to converge and continue the process of catching-up with the old members of the Union. So far, this process has progressed successfully: in 2004, the GDP per capita in Poland was only 50\% of the EU average, but by 2015 it was already $69 \%$.

Accession to the EU brought new possibilities for Polish consumers and businessmen. The support for farmers, structural funds for less developed regions and the unemployed, the new big market, and the transfer of knowledge and technology changed the standard of living considerably (Grosse 2015, pp. 24-56).

As for Armenia, there are difficult tasks which the economy has faced in the period of transitioning to the market economy and which need an urgent solution, such as overcoming poverty, deep polarization of incomes and the resulting social tensions of the population. Under the old Soviet central planning system, Armenia developed a modern industrial sector, supplying machine tools, textiles, and other manufactured goods to sister republics in exchange for raw materials and energy. After the collapse of the Soviet Union, the situation became grave, exacerbated 
by the constraints of demography and geography, as a small, landlocked country with few natural resources. For Armenia, this early phase of independence was marred by war, blockades and economic collapse, culminating in severe shortages of food, electricity and fuel. These conditions also predetermined the development of the economic system, and seriously distorted reform (Giragosian 2017, p. 11). The "struggle for survival" (1991-1994) in the first several years of independence was followed by a "period of recovery," when the nation managed to rebuild some of its capacities lost during the years of severe crises (Musayelyan 2009, p. 10). The economy today is market-oriented and highly receptive to trade, capital and technological innovation. From the late 1990s to 2007, GDP expanded very quickly, and Armenia now ranks as a lower middle-income country.

In order to evaluate the dynamics of the standard of living in Poland and Armenia,let us start by looking at the analysis of trends in gross domestic product per capita, the most commonly used indicator for demonstrating changes in the level of economic development.

Figure 1 shows the trends in gross domestic product per capita in purchasing power parity in Poland in the years 1990-2015.

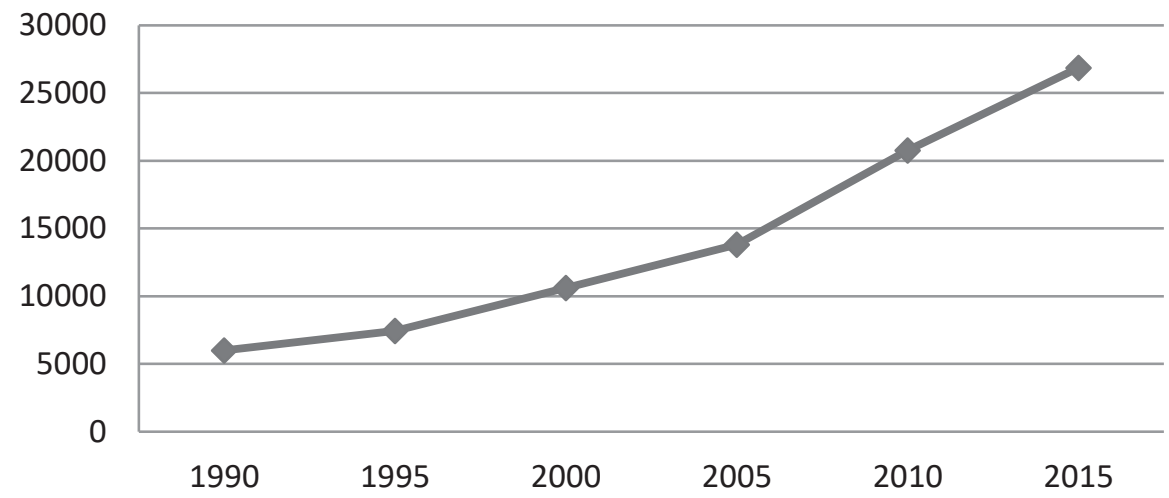

Figure 1. Gross domestic product per capita in purchasing power parity in Poland in the years 1990-2015 (in current international dollars)

Source: http://www.data.worldbank.org/country/poland

The data in Figure 1 confirm that the Polish economy is expanding, raising its level of economic development, as evidenced by the more than fourfold increase in GDP per capita in the period under study. Since 1992, Polish GDP has not shown any decline.

Figure 2 represents gross domestic product per capita in purchasing power parity in Armenia in the years 1990-2015.

During the period of transformation in the years 1990-1995, Armenia experienced a decline in GDP per capita. GDP growth took place only after 1994, with the level of GDP per capita only achieving the 1990 level in 2001. Gross domes- 
tic product per capita in the years 1990-2015 in Armenia increased by $248.6 \%$. Economic growth took place in both countries during the period under study, and GDP per capita shows an upward trend; however, the trend was stronger in Poland than in Armenia.

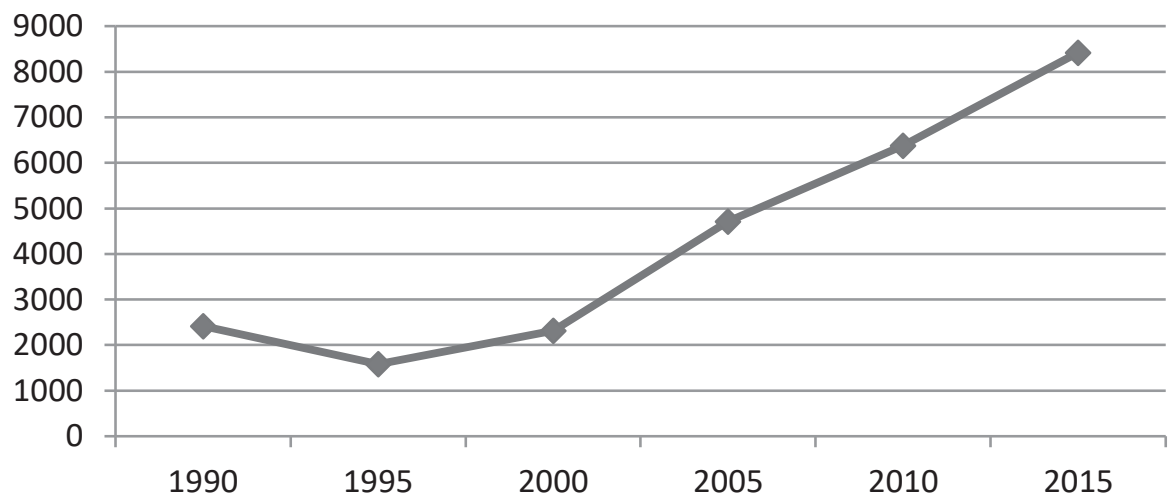

Figure 2. Gross domestic product per capita in purchasing power parity in Armenia in the years 1990-2015 (in current international dollars)

Source: http://www.data.worldbank.org/country/armenia

Both in Armenia and Poland, GDP per capita demonstrated an upward trend during 2006-2015. The growth rates of GDP per capita were a little bit stronger in Armenia than in Poland. During the period 2006-2015, the above-mentioned indicator increased about 1.64 times in Armenia, going from 2126.6 US dollars in 2006 to 3489.1 US dollars in 2015. For Poland, GDP per capita increased 1.38 times during the same period, going from 9040.8 US dollars in 2006 to 12554.5 US dollars in 2015. It is worth noting that, in 2015, GDP per capita in Poland exceeded the same indicator in Armenia 3.6 times. Despite the fact that the economy of Armenia is developing and expanding, the growth rates are still slow and insufficient.

The next indicator which describes a population's standard of living is human the development index. Over the last few decades the concept of the human development index has been used more and more by various governments to analyze the level of the standard of living. UN member countries completely or partly measure development using the human development index indicators (HDI) developed by the UN, as well as the calculation methodology, which is regularly improved. Based on these measurements, every year the UN summarizes and publishes country reports on Human Development. At the same time, the UN always encourages countries to take part in the improvement of the above-mentioned indicators and methodology. Nowadays, the HDI has become a better index describing the progress of the population than numerous other indicators, in particular, GDP. The methodology of calculating HDI is changeable. Human development is an opportunity for people to live a life that would be appreciated. The three 
traditional dimensions of HDI (life expectancy, good education and incomes that ensure decent living standards) are considered to be the basis. There is one more dimension, which is no less important. It is to live in a non-polluted environment and in harmony with nature.

In recent years, the concepts of human development and sustainable development became closer and started to complement each other. The concept of sustainable development has become more meaningful. In Armenia, the methodology of a system for evaluating, measuring and calculating sustainable human development was developed in 1995. Table 1 represents the changes in human development indices in Armenia and Poland in the years 1990-2015.

Table 1. The dynamics of human development indices in Armenia and Poland in the period 1990-2015

\begin{tabular}{|c|c|c|}
\hline Years & Armenia & Poland \\
\hline 1990 & 0.63 & 0.71 \\
\hline 1995 & 0.61 & 0.74 \\
\hline 2000 & 0.65 & 0.79 \\
\hline 2005 & 0.70 & 0.81 \\
\hline 2010 & 0.72 & 0.83 \\
\hline 2015 & 0.73 & 0.84 \\
\hline
\end{tabular}

Source: UNDP Human development report 2016, http://hdr.undp.org/en/indicators/137506, Human development indices 1990-2015/

We can see that both countries recorded improvements, although the situation is more desirable in Poland than in Armenia. During the last 25 years, HDI grew from 0.63 to 0.73 in Armenia, and from 0.71 to 0.84 in Poland.

Poland is in the first group of countries with a very high level of the human development index while Armenia is in the second group of countries with a high level of human development index.

The structure of HDI in Poland compared to Armenia shows that the following components are higher: average life expectancy (more than 76 years) and GNP per capita (more than 21 thousand USD in PPP).

The same indicators accounted for slightly more than 74 years and 3 thousand USD in PPP in Armenia, respectively. Regarding the components, the average years of education and expected years of education in these countries accounted for 10 and 15.3 years, respectively, in Poland and 11 and 12 years in Armenia. In this context, it is worth mentioning the global characteristics of the index components: the index was 0.682 , the average life expectancy -70 years, average education 7.4 years, expected years of education 11.3 years, national income per capita 11 thousand USD in PPP.

An economically active population includes two groups: the employed and the unemployed. The employed population includes people who, during the survey period, worked on a paid basis or were self-employed. It was not important if the job 
was permanent, temporary, seasonal or one-off, or even if the work was one hour during the survey period. The unemployed are people who are able to work, who are searching work and can start working immediately. Employment is a very important component of the high standard of living of a population.

Table 2. Employment in Armenia and Poland in the years 2006-2015

\begin{tabular}{|c|c|c|c|c|c|c|}
\hline \multirow{2}{*}{ Years } & \multicolumn{2}{|c|}{$\begin{array}{c}\text { Economically active } \\
\text { population (in 1000 persons) }\end{array}$} & \multicolumn{2}{|c|}{$\begin{array}{c}\text { Employed population } \\
\text { (in 1000 persons) }\end{array}$} & $\begin{array}{c}\text { Percentage of employed } \\
\text { population in the } \\
\text { economically active } \\
\text { population }\end{array}$ \\
\cline { 2 - 7 } & Armenia & Poland & Armenia & Poland & Armenia & Poland \\
\hline 2006 & 1181.3 & 15774.1 & 1092.4 & 13220.0 & 92.5 & 83.8 \\
\hline 2007 & 1184.3 & 15773.0 & 1101.5 & 13771.1 & 93.0 & 87.3 \\
\hline 2008 & 1192.5 & 15565.2 & 1117.6 & 14037.2 & 93.7 & 90.2 \\
\hline 2009 & 1170.8 & 15479.9 & 1089.4 & 13782.3 & 93.0 & 89.0 \\
\hline 2010 & 1188.1 & 16050.3 & 1104.8 & 14106.9 & 93.0 & 87.9 \\
\hline 2011 & 1440.9 & 16245.7 & 1175.1 & 14232.6 & 81.6 & 87.6 \\
\hline 2012 & 1418.3 & 16255.4 & 1172.8 & 14172.0 & 82.7 & 87.2 \\
\hline 2013 & 1388.4 & 16473.7 & 1163.8 & 14244.3 & 83.8 & 86.5 \\
\hline 2014 & 1375.7 & 16613.8 & 1133.5 & 14563.4 & 82.4 & 87.7 \\
\hline 2015 & 1316.4 & 16566.5 & 1072.6 & 14829.8 & 81.5 & 89.5 \\
\hline
\end{tabular}

Source: Own calculations based on data from the Statistical Yearbook of Armenia 2006-2016, National Statistical Service of Armenia, http://www.armstat.am; Employment in national economy 2006-2015, Central Statistical Office of Poland, http://www.stat.gov.pl

Table 2 describes employment in Armenia and Poland in the years 2006-2015. The economically active population increased in both countries during the observed 10 years. Despite this fact, the number of employed people and their share in the economically active population in Armenia decreased from 1092.4 thousand people $(92.5 \%)$ to 1072.6 thousand people $(81.5 \%)$. This means that the unemployment rate had an upward trend during the period under study. Regarding Poland, the number of employed people and their share in the economically active population increased from 13220.0 thousand people (83.8\%) to 14829.8 thousand people $(89.5 \%)$. So, there was a downward trend in the unemployment rate in Poland.

\section{The dynamics of income, expenditures and consumption structures in Armenia and Poland in the period 2006-2015}

In order to get a clear understanding of the living standard of a population, first of all, it is necessary to study the composition and structure of household income and expenditure. 
The level of incomes of members of society is the main indicator of the well-being of the population. Besides the salary level, the income level of the population is also affected by the level of retail prices and the level of saturation of the market by consumer goods. In the context of the development of society, the growth of the income of the population is the main aspect which contributes to the development of an individual. From this perspective, between income growth and human development, there is separated not only the accumulation of wealth, but also its distribution and circumstances of its use. The fair distribution of income expands people's opportunities to choose and allows the standard of living to be raised. The connection between the income of the population and the quality of life should be shaped by policies which governments adopt, including social and fiscal policies. The market mechanism of the economy does not guarantee a level of prosperity for society. In real life, the distribution of the income of the population is realized not only by the labor market, but also through the regulation of different sources of income through its redistribution. When studying the standard of living of the population, it is vital to assess not only the income level, but also the quantitative measurement of potential opportunities of the population in using those resources to purchase goods and services. For these purposes, the purchasing power of monetary incomes of an entire population or its groups is calculated.

The indicators of standard of living are closely linked to the overall level of socio-economic development of a country and its regions. Low real incomes of the majority of the population mean that food is not affordable for them and it has a negative impact on the quality of food.

The monetary value of goods and services that the average household consumes during a certain period of time, which corresponds to a certain level of satisfaction of needs, is called value of life. Only the real household income per capita is the dynamic indicator which describes the living conditions and standard of living of households.

In order to understand the changes in standard of living of the populations of Armenia and Poland, let us examine the structures of income, expenditures and consumption in the years 2006-2015 and make a comparative analysis.

Table 3 provides information of the monthly incomes in households in Armenia in the years 2006-2015 (per capita, in constant 2005 US dollars). Analyzing the data from the table, we can see that total monetary incomes and all their components experienced an increase during the studied period.

The next table shows the dynamics of expenditures in Armenia in the same period. Total consumer expenditures increased 1.8 times, amounting to 92.1 US dollars in 2015. All the components of total consumer expenditures had an increasing trend.It is important to mention that the growth rate of total monetary incomes was stronger than the growth rate of total consumer expenditures. 
Table 3. Monthly income of households in Armenia in the years 2006-2015 (per capita, in constant 2005 US dollars)

\begin{tabular}{|c|c|c|c|c|}
\hline Years Income & $\begin{array}{c}\text { Total monetary } \\
\text { incomes }\end{array}$ & Labor incomes & Social transfers & Other incomes \\
\hline 2006 & 40.3 & 24.9 & 5.6 & 9.8 \\
\hline 2007 & 48.7 & 31.7 & 6.7 & 10.3 \\
\hline 2008 & 58.7 & 36.9 & 10.6 & 11.2 \\
\hline 2009 & 61.3 & 36.8 & 12.3 & 12.1 \\
\hline 2010 & 68.9 & 41.4 & 12.9 & 14.7 \\
\hline 2011 & 74.7 & 44.7 & 14.2 & 15.8 \\
\hline 2012 & 85.3 & 51.3 & 15.7 & 18.3 \\
\hline 2013 & 92.6 & 55.3 & 16.6 & 20.8 \\
\hline 2014 & 108.2 & 65.8 & 18.2 & 24.3 \\
\hline 2015 & 113.7 & 68.7 & 18.9 & 26.1 \\
\hline
\end{tabular}

Source: http://www.armstat.am, National Statistical Service of Armenia,

Living conditions 2005-2014.

Table 4. Monthly expenditures of households in Armenia in the years 2006-2015 (per capita, in constant 2005 US dollars)

\begin{tabular}{|c|c|c|c|c|}
\hline Years & $\begin{array}{c}\text { Total } \\
\text { consumer } \\
\text { expenditures }\end{array}$ & $\begin{array}{c}\text { Food goods } \\
\text { (including } \\
\text { tobacco) }\end{array}$ & $\begin{array}{c}\text { Non-food } \\
\text { goods }\end{array}$ & Services \\
\hline 2006 & 50.9 & 31.3 & 7.1 & 12.5 \\
\hline 2007 & 57.5 & 33.4 & 9.0 & 15.1 \\
\hline 2008 & 63.1 & 35.5 & 10.3 & 17.3 \\
\hline 2009 & 60.4 & 33.7 & 9.4 & 17.4 \\
\hline 2010 & 62.6 & 35.2 & 9.7 & 17.7 \\
\hline 2011 & 71.2 & 40.5 & 11.0 & 19.7 \\
\hline 2012 & 76.3 & 40.4 & 13.5 & 22.4 \\
\hline 2013 & 80.4 & 41.8 & 14.4 & 24.2 \\
\hline 2014 & 89.1 & 44.3 & 16.3 & 28.5 \\
\hline 2015 & 92.1 & 46.7 & 17.0 & 28.4 \\
\hline
\end{tabular}

Source: http://www.armstat.am, National Statistical Service of Armenia, Living conditions 2005-2014.

Despite the decrease in the share of expenditures on food goods, they still have a big share in the total. This decrease is a positive sign, assuming that the population of Armenia started to spend more on non-food goods and services. This means that the economy of the country is developing, and the living standards are gradually increasing. The expense/income ratio amounted 1.3 in 2006 and 0.81 in 2015, which means that living standards are increasing in Armenia. We can see that expenses exceeded incomes in 2006.

The research on different household budgets shows that the smaller a household budget, the more that is spent on purchasing food products, moreover, acquir- 
ing low-quality food. If a household budget is small, more of it is directed to human life, and a small portion is given to spiritual development.

Now let us look at how income and the expenditures structures of households changed over time in Poland.

Table 5 demonstrates the data on monthly incomes of households in Poland in the years 2006-2015 (per capita, in constant 2005 US dollars). Total monetary incomes increased 1.6 times during the period 2006-2015, reaching 421.8 US dollars in 2015. It is worth noting that all the components of incomes recorded an increase.

Table 5. Monthly incomes of households in Poland in the years 2006-2015 (per capita, in constant 2005 US dollars)

\begin{tabular}{|c|c|c|c|c|}
\hline Years & $\begin{array}{c}\text { Total } \\
\text { monetary } \\
\text { incomes }\end{array}$ & Labor incomes & $\begin{array}{c}\text { Social } \\
\text { transfers }\end{array}$ & Other incomes \\
\hline 2006 & 258.1 & 144.6 & 86.6 & 26.9 \\
\hline 2007 & 287.2 & 170.0 & 87.5 & 29.7 \\
\hline 2008 & 323.3 & 201.7 & 92.4 & 29.2 \\
\hline 2009 & 344.6 & 214.9 & 99.7 & 30.0 \\
\hline 2010 & 368.9 & 230.6 & 104.2 & 34.0 \\
\hline 2011 & 381.8 & 238.4 & 111.4 & 32.0 \\
\hline 2012 & 395.3 & 245.6 & 114.2 & 35.5 \\
\hline 2013 & 401.7 & 248.0 & 117.0 & 36.7 \\
\hline 2014 & 414.5 & 259.2 & 119.9 & 35.5 \\
\hline 2015 & 421.8 & 262.2 & 121.3 & 38.3 \\
\hline
\end{tabular}

Source: Own calculations based on the data from http://www.stat.gov.pl,

Statistical Yearbook of the Republic of Poland, Household budgets, Average monthly available income in households 2007-2015.

The next table shows the expenditures of households in Poland in the same period. The total consumer expenditures saw a $47.6 \%$ increase during that period, whilst the expenditures on food goods rose at a slower pace - $31 \%$. It means that the share of expenditures on non-food goods and services is increasing quickly.

Table 6. Monthly expenditures of households in Poland in the years 2006-2015 (per capita, in constant 2005 US dollars)

\begin{tabular}{|c|c|c|c|c|}
\hline Years & $\begin{array}{c}\text { Total } \\
\text { Expenditure } \\
\text { expenditures }\end{array}$ & $\begin{array}{c}\text { Food goods } \\
\text { (including } \\
\text { tobacco) }\end{array}$ & $\begin{array}{c}\text { Non-food } \\
\text { goods }\end{array}$ & Services \\
\hline 2006 & 220.3 & 68.7 & 35.9 & 115.8 \\
\hline 2007 & 239.8 & 73.5 & 41.4 & 124.9 \\
\hline 2008 & 267.6 & 78.8 & 45.3 & 143.5 \\
\hline 2009 & 282.6 & 82.3 & 46.9 & 153.4 \\
\hline
\end{tabular}




\begin{tabular}{|c|c|c|c|c|}
\hline Years & $\begin{array}{c}\text { Total } \\
\text { consumer } \\
\text { expenditures }\end{array}$ & $\begin{array}{c}\text { Food goods } \\
\text { (including } \\
\text { tobacco) }\end{array}$ & $\begin{array}{c}\text { Non-food } \\
\text { goods }\end{array}$ & Services \\
\hline 2010 & 294.1 & 85.0 & 48.2 & 160.9 \\
\hline 2011 & 301.9 & 87.6 & 47.5 & 166.8 \\
\hline 2012 & 310.8 & 90.4 & 48.3 & 172.1 \\
\hline 2013 & 314.7 & 90.2 & 50.9 & 173.5 \\
\hline 2014 & 319.0 & 89.9 & 53.5 & 175.6 \\
\hline 2015 & 325.3 & 90.3 & 55.7 & 179.3 \\
\hline
\end{tabular}

Source: Own calculations based on the data from http://www.stat.gov.pl,

Statistical Yearbook of Republic of Poland, Household budgets, Average monthly expenditures in households 2007-2015.

It is obvious that both total monetary incomes and total consumer expenditures increased during the period under study, while the growth rate of total monetary incomes is stronger than the growth rate of total consumer expenditures. The expense/income ratio amounted to 0.85 in 2006 and 0.77 in 2015, which means that living standards are increasing in Poland too.

In the sphere of regulating the incomes of the population, economic policy should be directed to preserving the state's guarantee of a minimum wage. Redistribution of national income is one of the main target functions of the state, and to do this, the state develops appropriate programs for the sustainable distribution of income of the population. In addition, the state is responsible for the protection of the incomes of public sector workers who receive a fixed income. Usually, this is done by increasing the real level of the minimum wage.

It is unacceptable to maintain such a situation where the minimum wage is not in line with the vital minimum, as in the Republic of Armenia. In the sphere of settling the income of the population, the economic policy should be aimed at the preservation of the state's guarantee of a minimum wage. Within the framework of the solutions to these problems, setting the minimum wage, we suggest taking into account the level of inflation in the country, the minimum budget or the minimum consumer basket, as well as the average salary. A centrally-set minimum remuneration for work is reviewed in accordance with the simultaneous formation of economic conditions(inflation, devaluation) or when there is an increase in production efficiency and the accumulation of financial resources.

The implementation of a work remuneration function in the conditions of a market economy implies that a minimum level will be determined through calculating a vital minimum, a level below which it must not fall. The Consumer basket is the commonly used method for determining the vital minimum. The minimum acceptable consumer set or consumer basket is a list of consumer goods and services which are necessary for someone to live a normal life.

The composition and structure of the basket is based on the actual consumption of the population, which is obtained through household surveys, and this val- 
ue varies according to changes in consumer prices. The composition of food products included in food balance sheets varies from country to country and includes the most widely consumed products in a specific country. That is why products with small-scale consumption are not presented in balance sheets. Food balances are necessary to evaluate the risks associated with insufficient food supply and for a complete description of a country's food security at certain period of time. Food balances are compiled by statistical agencies for each calendar year (UN Office for Armenia 2005, p. 4)

In Armenia, national food balance sheets have been compiled every year since 2001. The National Statistical Service of Armenia compiled food balances for the following 14 types of products until 2012: wheat, potatoes, vegetables, fruit (except grapes), leguminous crops, vegetable oil, sugar, eggs, milk, beef meat, pork meat, mutton and goat meat, poultry meat, grapes. In 2013, 7 more types of food products were included in the balances: rye, barley, oats, maize, rice, other cereals, and fish, bringing the total to 21 . These changes were reflected in the 2009-2011 balance sheets; those 7 types of food products were included in the previous balances.

The National Statistical Service of Armenia uses an aggregate consumption indicator as a base when assessing the level of poverty in the country. It is considered more reliable indicator compared with the income indicator, as the latter is usually concealed or indicated less than it really is by the respondents of the survey. The consumption indicator shows the current standard of living. It includes the following components: consumption of food (including food consumption outside the home), expenditures on non-food products and services, including some durable goods, as well as non-food goods and services received for free in monetary value. The consumer budget is directly related to the standard of living of the population, which sums up the demand of the population for material goods and services according to social, age and gender groups, place of residence, work conditions and workload.

The following table represents the structure of expenditures of the population on purchasing food products in Armenia in the years 2006-2015 (in \%). During last ten years, the dynamics of the shares of the components of food and non-alcoholic beverages changed slightly. Expenditures on bread and bakery products, butter and fats, sugar, tea, coffee, and sweets declined, while expenditures on meat, poultry and fish, dairy products and eggs, fruits and vegetables, and other foodstuffs had an increase.

Of course, it is positive that the population spends more on healthful products like milk, meat, fruits and vegetables, while there are decreases in the share of expenditures on bread and bakery products, butter and fats, and others. At the same time, we cannot forget the different growth rates in the prices of these food products, which is one of the main reasons for changes in the structure of expenditures of the population. Regarding alcoholic beverages and tobacco, during this period there were some fluctuations in its share, but mainly the proportion of the latter and food and non-alcoholic beverages stayed almost the same. 
Table 7. The structure of expenditures of the population on purchasing food products in Armenia in the years 2006-2014 (in \%)

\begin{tabular}{|c|c|c|c|c|c|c|c|c|c|c|}
\hline \multicolumn{2}{|c|}{$\begin{array}{ll}\text { Products } & \text { Years } \\
\end{array}$} & 2006 & 2007 & 2008 & 2009 & 2010 & 2011 & 2012 & 2013 & 2014 \\
\hline \multicolumn{2}{|c|}{ Food products } & 100 & 100 & 100 & 100 & 100 & 100 & 100 & 100 & 100 \\
\hline \multicolumn{2}{|c|}{$\begin{array}{l}\text { Food and non-alcoholic } \\
\text { beverages }\end{array}$} & 89.6 & 90.3 & 90.7 & 90.1 & 90.4 & 90.3 & 90.5 & 90.3 & 90.3 \\
\hline \multirow{8}{*}{$\begin{array}{l}\frac{-}{0} \\
\frac{1}{3} \\
\frac{4}{0}\end{array}$} & $\begin{array}{l}\text { Bread and bakery } \\
\text { products }\end{array}$ & 21.0 & 20.3 & 22.8 & 20.5 & 19.9 & 20.1 & 20.8 & 21.2 & 19.7 \\
\hline & $\begin{array}{l}\text { Meat, poultry } \\
\text { and fish }\end{array}$ & 20.7 & 20.5 & 20.0 & 20.6 & 20.5 & 20.5 & 22.2 & 22.0 & 21.7 \\
\hline & $\begin{array}{l}\text { Dairy products } \\
\text { and eggs }\end{array}$ & 11.0 & 11.2 & 11.1 & 11.3 & 10.8 & 10.7 & 11.2 & 11.2 & 11.9 \\
\hline & Butter and fats & 6.3 & 6.1 & 6.7 & 6.4 & 6.1 & 6.1 & 6.2 & 5.9 & 6.0 \\
\hline & \begin{tabular}{|l|} 
Fruits and \\
vegetables \\
\end{tabular} & 17.5 & 17.7 & 16.6 & 17.2 & 18.7 & 18.7 & 17.2 & 17.1 & 18.4 \\
\hline & $\begin{array}{l}\text { Sugar, tea, coffee, } \\
\text { sweets }\end{array}$ & 8.7 & 8.7 & 8.5 & 9.4 & 9.2 & 9.2 & 8.2 & 7.4 & 7.2 \\
\hline & $\begin{array}{l}\text { Non-alcoholic } \\
\text { beverages }\end{array}$ & 1.0 & 1.3 & 1.1 & 1.0 & 1.1 & 1.1 & 1.2 & 1.1 & 1.2 \\
\hline & Other foodstuffs & 3.4 & 4.5 & 3.9 & 3.7 & 4.1 & 4.0 & 3.5 & 4.4 & 4.2 \\
\hline \multicolumn{2}{|c|}{$\begin{array}{l}\text { Alcoholic beverages } \\
\text { and tobacco }\end{array}$} & 10.4 & 9.7 & 9.3 & 9.9 & 9.6 & 9.6 & 9.5 & 9.7 & 9.7 \\
\hline
\end{tabular}

Source: http://www.armstat.am, National Statistical Service of Armenia, Living conditions 2006-2015.

Table 8 demonstrates the data on the structure of expenditures of the population on purchasing food products in Poland in the years 2006-2015 (in \%). In the case of Poland, the share of food and non-alcoholic beverages decreased over time while the share of alcoholic beverages and tobacco increased by $0.5 \%$. Regarding the dynamics of the components of food and non-alcoholic beverages, there was a decrease in the share of expenditures on bread and bakery products, meat, poultry and fish, dairy products and eggs, butter and fats, sugar, tea, coffee, and sweets. The share of expenditures on fruits and vegetables, non-alcoholic beverages and other foodstuffs increased.

Total monetary incomes and total consumer expenditures and their components had exclusively increasing trends in both countries during the period under study. Despite some changes in the monthly income structure, the share of labor incomes is predominant, amounting to about $2 / 3$ of the total monthly income of households in both countries. As for the monthly consumer expenditures structure, the situation is different in Armenia and Poland. Expenditures on food goods (including tobacco) equal half of the monthly consumer expenditures of households in Armenia. The expenditures on non-food goods and services make up a relatively small share of the total. This type of structure is specific for developing countries without a high level of living standard. Despite this fact, it is obvious that the situation is improving in Ar- 
menia, i.e., the share of expenditures on food goods (including tobacco) is gradually decreasing, and the share of services is increasing. Poland has another structure of consumer expenditures. The major part of monthly consumer expenditures is the expenditure on services, which is more than half of the total. Expenditures on food goods (including tobacco) make up a small share and are gradually decreasing. This type of consumer expenditures structure is typical for countries which have a developed economy. The shares of expenditures on non-food goods were more or less stable in both countries. The structure of consumption of main food products of households is different in Armenia and Poland. Wheat bread, pasta products and meat are the products which have a high consumption level in Armenia. Despite the decreasing trend in the consumption level of wheat bread in Armenia during the last decade, its level is too high. Bread, meat and milk are the most consumed products in Poland. The consumption level of meat and milk is much higher in Poland than in Armenia.

Table 8. The structure of expenditures of the population on purchasing food products in Poland in the years 2006-2014 (in \%)

\begin{tabular}{|c|c|c|c|c|c|c|c|c|c|c|}
\hline \multicolumn{2}{|c|}{$\begin{array}{ll}\text { Products } & \text { Years } \\
\end{array}$} & 2006 & 2007 & 2008 & 2009 & 2010 & 2011 & 2012 & 2013 & 2014 \\
\hline \multicolumn{2}{|c|}{ Food products } & 100 & 100 & 100 & 100 & 100 & 100 & 100 & 100 & 100 \\
\hline \multicolumn{2}{|c|}{$\begin{array}{l}\text { Food and non-alcoholic } \\
\text { beverages }\end{array}$} & 91.0 & 90.8 & 90.6 & 90.2 & 90.1 & 90.2 & 90.3 & 90.6 & 90.6 \\
\hline \multirow{8}{*}{$\begin{array}{l}\frac{7}{0} \\
\frac{1}{3} \\
4 \\
0\end{array}$} & $\begin{array}{l}\text { Bread and bakery } \\
\text { products }\end{array}$ & 14.1 & 14.5 & 15.0 & 14.6 & 14.4 & 14.8 & 14.6 & 14.2 & 14.2 \\
\hline & $\begin{array}{l}\text { Meat, poultry } \\
\text { and fish }\end{array}$ & 27.5 & 27.3 & 27.0 & 27.6 & 26.6 & 26.7 & 27.2 & 27.0 & 27.2 \\
\hline & $\begin{array}{l}\text { Dairy products } \\
\text { and eggs }\end{array}$ & 13.1 & 13.0 & 13.2 & 12.8 & 13.1 & 13.0 & 13.3 & 12.7 & 12.8 \\
\hline & Butter and fats & 4.5 & 4.3 & 4.3 & 4.2 & 4.1 & 4.3 & 4.2 & 4.1 & 4.0 \\
\hline & $\begin{array}{l}\text { Fruits and } \\
\text { vegetables }\end{array}$ & 15.5 & 15.5 & 14.9 & 14.6 & 15.4 & 14.6 & 13.9 & 14.7 & 14.8 \\
\hline & $\begin{array}{l}\text { Sugar, tea, coffee, } \\
\text { sweets }\end{array}$ & 8.9 & 8.6 & 8.5 & 8.5 & 8.4 & 8.9 & 9.0 & 8.9 & 8.4 \\
\hline & $\begin{array}{l}\begin{array}{l}\text { Non-alcoholic } \\
\text { beverages }\end{array} \\
\end{array}$ & 4.3 & 4.4 & 4.5 & 4.5 & 4.6 & 4.6 & 4.7 & 4.6 & 4.7 \\
\hline & Other foodstuffs & 3.1 & 3.2 & 3.3 & 3.4 & 3.5 & 3.3 & 3.4 & 4.4 & 4.5 \\
\hline \multicolumn{2}{|c|}{$\begin{array}{l}\text { Alcoholic beverages } \\
\text { and tobacco }\end{array}$} & 9.0 & 9.2 & 9.3 & 9.8 & 9.9 & 9.8 & 9.7 & 9.4 & 9.4 \\
\hline
\end{tabular}

Source: Own calculations based on the data from http://www.stat.gov.pl,

Statistical Yearbook of Republic of Poland, Household budgets, Average monthly expenditures in households 2007-2015.

When examining the structures of expenditures of populations on purchasing food products in both countries, we can see that the proportion of food and non-alcoholic beverages and alcoholic beverages and tobacco is almost the same in Armenia as in Po- 
land. Bread and bakery products, meat, poultry and fish, and fruits and vegetables make up a big share of food and non-alcoholic beverages in both Armenia and Poland.

\section{Conclusions}

The standard of living of a population has a special and important place in the concept of human development. Standard of living is a broad concept and it is obvious that there is no perfect indicator characterizing it.

In the phase of transitioning to a market economy, Armenia has faced such difficult tasks as overcoming poverty, deep social polarization and the resulting social tension, and it urgently needs solutions. The low real incomes of the majority of the population mean that food is not affordable and it has a negative impact on the quality of food. Overall, there were positive changes in income, expenditures and consumption structures in both countries during the last decade, which reflects the increase in living standards.

Total monetary incomes and total consumer expenditures and their components had exclusively increasing trends in both countries during the period under study. Despite some changes in the monthly income structure, the share of labor incomes is predominant, amounting to about $2 / 3$ of the total monthly income of households in both countries. Regarding the structure of monthly consumer expenditures, the situation is different in Armenia and Poland. The expenditures on food goods consist half of the monthly consumer expenditures of households in Armenia. The expenditures on non-food goods and services have a relatively small share in the total. This type of structure is specific for developing countries with a not high level of living standard. Despite this fact, it is obvious that the situation is improving in Armenia, i.e., the share of the expenditures on food goods (including tobacco) is gradually decreasing, and the share of services is increasing.

Poland has a different structure of consumer expenditures. The major part of monthly consumer expenditures is on services, which takes up more than half of the total. The expenditures on food goods (including tobacco) make up a small share and are gradually decreasing. This type of consumer expenditure structure is typical of countries which have a developed economy. The shares of the expenditures on non-food goods were more or less stable in both countries. The structure of the consumption of the main food products in households is different in Armenia and Poland.

European integration in the framework of the Eastern Partnership may have a significantly positive impact on the development of the economy of Armenia. After the launch of the Eastern Partnership in 2009, the values of imports and exports of food products between Armenia and Poland recorded incomparable growth. 
The deepening of the cooperation between Armenia and Poland in the framework of the Eastern Partnership could contribute to an increase in the standard of living of both countries. However, it is not a short-term process, because the countries have to overcome many political and economic challenges.

\section{References}

Gevorgyan, M., Margaryan, P. (1994), The concept of state economic policy, its essence and principles; 'Economics', Yerevan, Nos. 1-2.

Giragosyan, R. (2017), The Political Dimension: Armenian Perspective, in: The South Caucasus 2018. Facts, Trends. Future Scenarios, Konrad Adenauer Stiftung, Tbilisi.

Grosse, T.M. (2015), Rozkwit, rozbłysk czy wypalenie? Blaski i cienie 10 lat członkostwa w Unii Europejskiej, [in:] Witkowska M., Bilans polskiego członkostwa w Unii Europejskiej, Uniwersytet Warszawski, Warsaw.

https://www.armstat.am

https://www.cba.am/AM/panalyticalmaterialsresearches/HDR-2303.12pdf

https://www:data.worldbank.org/country/

http://www.stat.gov.pl

https://www.wits.worldbank.org

Kołodko, G.W., Nuti, M.D. (1997), Polska alternatywa, Stare mity, twarde fakty, nowe strategie, Poltext, Warsaw.

Manaseryan, T. (2000), The outline of a new economic policy; Yerevan.

National Statistical Service of Republic of Armenia (2016), Statistical Yearbook of Armenia 2005-2015, Yerevan.

Sen, A. (1985), The Standard of Living, The Tanner Lectures on Human Values, Cambridge University, March 11-12.

Smeeding, T.M., Rainwater, L. (2002), Comparing Living Standards Across Nations: Real incomes at the Top, the Bottom and the Middle, SPRC Discussion Papers, No. 120.

UN Office in Armenia (2005), Human poverty and pro-poor policy, Yerevan.

UNDP Human development report 2016, http://hdr.undp.org/en/indicators/137506, Human development indices 1990-2015

Vardanyan, G. (2002), The standard of living of the population of Armenia as an object of statistical research, Kantegh, digest of scientific articles, No. 5, Asoghik, Yerevan.

Vardanyan, G., Vardanyan, H. (2008), Statistical study of household expenditures in RA over the last decade, Socio-economic development issues in Russian Federation and Republic of Armenia; Materials of international scientific-practical conference, Yerevan,

Vardanyan, G., Vardanyan, H., Mamikonyan, G. (2009), Comparative interregional analysis of the indices characterizing the economic development level of the regions, Bulletin of State Agrarian University of Armenia, "International Scientific Journal", 2 (26) 2009, Yerevan. 


\section{Streszczenie}

\section{STANDARD ŻYCIA SPOLECZEŃSTWA: ANALIZA PORÓWNAWCZA POLSKI I ARMENII}

Standard życia spoleczeństwa odgrywa specjalna $i$ ważna rolę $w$ koncepcji rozwoju społecznego. Można przyjąć, że im wyższy jest standard życia społeczeństwa, tym większe sa szanse na rzeczywisty rozwój społeczeństwa. Standard życia wyraża pewien poziom zaspokojenia potrzeb społeczeństwa, gdyż żadne społeczeństwo nie jest $w$ stanie zaspokoić wszystkich potrzeb własnych mieszkańców. Standardu życia nie można wyrazić za pomoca pojedynczych wskaźników, gdyż jest to pojęcie złożone uwzględniające zarówno aspekty jakościowe, jak i ilościowe. Standard życia zazwyczaj charakteryzuje się biorac pod uwage system wskaźników odnoszacych się nie tylko do sfery makroekonomicznej, ale również mikroekonomicznej.

Celem artykułu jest próba porównania standardu życia w Polsce $i$ w Armenii. Obydwa kraje należały do dawnego bloku wschodniego, w którym dominowała gospodarka centralnie planowana i która odcisnęła również piętno na jakości życia społeczeństw. Po upadku systemu socjalistycznego, w obu krajach nastapił zwrot w kierunku gospodarki kapitalistycznej $i$ wejście na ścieżkę rozwoju.

Słowa kluczowe: standard życia, jakość życia, rozwój społeczny 